\title{
Effect of Striga Infestation on Sorghum Agronomic Traits and Its Breeding Strategy for Resistance in Ethiopia: A Review
}

\author{
Tamirat Bejiga \\ Melkassa Agriculture Research Center, P.O Box 346, Adama, Ethiopia
}

\begin{abstract}
In Ethiopia sorghum is a major cereal crop grown in wide agroecology however, in most of moisture stress sorghum growing areas are infested by striga. Striga is an obligate root parasitic and a major biotic constraint to sorghum production in Ethiopia. Farmers sown susceptible sorghum varieties in striga infested field resulted plant height and dray matter and yield components were affected therefore, loss significant grain yield production. Farmers named reduction of sorghum growth and stunting as main indication of Striga infestation. Varieties exhibited lower reduction for these traits in striga infestation was named resistant varieties. In Ethiopian Gobiye, Abshir and Birhan registered as striga resistance, drought tolerant and early maturing varieties. Currently in Ethiopian sorghum national breeding program these resistance varieties utilizing as a source of resistance gene and crossing with landraces and other improved genotypes to develop new high grain yielding and resistance variety with farmers preferred agronomic traits. Also resistance variety SRN 39 and Framida use in breeding program. Resistance varieties also a central components of integrated striga management. The screening techniques is undergoing at major sorghum growing areas and striga infested field however, the striga occurrence is complicated and slow down the development of new resistance variety. Laboratory screening data conceding with field data was a mandatory to developed resistance varieties. Generally, enhancing sorghum grain yield production by developing high yielding stable striga resistance varieties, improving integrate striga controlling managements and distributing resistance varieties to the farmers are unambiguous. The objectives of this paper is to review the effect of striga on sorghum agronomic traits and breeding strategy.
\end{abstract}

Keywords: Striga infestation, Sorghum, resistance

DOI: $10.7176 / \mathrm{JBAH} / 9-15-06$

Publication date: August $31^{\text {st }} 2019$

\section{INTRODUCTION}

Sorghum is native to Sub-Saharan Africa and has been cultivated for centuries in Asia and Africa (Monica et al., 2004). The most important and old world cereal crops that was domesticated in Africa (Dahlberg et al., 2011). It is an annual crop that is tolerant, making it an excellent choice for dry areas. It has been found as an indigenous crop to Ethiopia with enormous genetic diversity.

The potential productivity of sorghum is reduced due to a number of abiotic and biotic stresses. The problems of various invasive and devastating weeds including striga are the major constraints especially in Africa and Ethiopia in particular (Mekonen, 2007). Striga spp. are obligate hemi-parasitic plants that attack to the roots of their host to obtain water, nutrient and carbohydrates (Ast, 2006). S.hermonthica mainly attacks sorghum, finger millet and maize in tropical and sub-tropical regions spreading across from West Africa to Ethiopia. In Ethiopia striga is a major biotic constraint and a serious threat to subsistence food production. Striga hermonthica, the dominant species which is severe in the highly degraded north, north western and eastern parts of the country vis Tigray, Wollo, Gonder, Gojam, north shewa and Harerghe (AATF, 2011).

Striga (witchweeds), are notorious root hemiparasites on cereal and legume crops grown in the semi-arid tropical and subtropical regions of Africa, the southern Arabian Peninsula, India, and parts of the eastern USA. These weed-parasites cause between 5 to $90 \%$ losses in yield; total crop loss data have been reported (Obilana et al., 1992). Striga infests and significantly reduces yields of cereal crops including rice, pearl millet, maize and sorghum (Rich et al., 2004). In Ethiopia, it is widely found in the lowland areas where sorghum is the dominant crop. Based on its infestation level sorghum yield loss due to Striga damage varies from place to place. On average sorghum yield losses of $65 \%$ were estimated in moderate to heavy infestations (Tesso et al., 2007).

The striga controlling method such as cultural, chemical, biological, and use of resistant varieties are either impracticable for the majority of small farmers or too expensive or unavailable due to different reasons to reduce Striga damage. No single method of control can provide an effective and economically acceptable solution. Therefore, an integrated control approach is essential, ideal and useful to small-scale farmers, in order to achieve sustainable crop production (Hayelom, 2014). Striga-resistant sorghums can be a major component of integrated striga control approaches if resistance is incorporated into adapted, productive cultivars. Resistant cultivars can reduce both new striga seed production and the striga seed bank in infested soils. However, breeding progress has been limited due to the difficulty of evaluating resistance in the field and inadequate information on the genetics of striga resistance (Haussmanna et al., 2000). In this paper, effect of striga on sorghum agronomic traits under striga infested, breeding for improved integrated striga control mechanisms and breeding for striga 
resistant in sorghum have been reviewed.

\section{LITERATURE REVIEW}

In Ethiopia, sorghum is grown as one of the major food cereals. Annually 1.3 million ha of land is allotted for sorghum production and 1.7 million ton of grain is produced in the country (Tadesse et al., 2008). A number of striga resistant sorghum cultivars developed and released by the Sorghum Research Program at Purdue University. These cultivars were carefully tested for field resistance to striga in collaboration with plant breeders in several countries (Table 1).

Table 1. Striga resistant sorghum cultivars developed and released at Purdue University and countries where cultivars have been officially adopted and widely distributed.

\begin{tabular}{llll} 
Designation & Country of release & Year of release & Local name \\
\hline SRN 39 & Sudan & 1991 & Mogawium buda 1 \\
P9830 & Sudan & 1991 & Mogawium buda 2 \\
P9401 & Ethiopia & 2000 & Gobiye \\
P9403 & Ethiopia & 2000 & Abshir \\
P9405 & Tanzania & 2002 & Hakika \\
P9406 & Tanzania & 2002 & Wahi \\
PSL5061 & Ethiopia & 2002 & Birhan \\
\hline
\end{tabular}

Source: Ejeta, 2005

\section{Constraints of Sorghum Production in Ethiopia}

The major factors that account for low yield in sorghum crop are moisture stress, low soil fertility and pest damages. Among the pests, the root parasitic weed Striga is greatest biological constraint to sorghum production. This problem is also common in the eastern semi-arid area which is one of the most sorghum producing areas of the country (Zerihun, 2016). Major Sorghum production constraints naming percentage described by farmers in Ethiopia at Dejen, Bessoliban and Motta was striga infestation than low soil fertility, moisture deficient and lack of production input (Mesfin, 2016).

\section{Distribution and host range of Striga}

The parasitic seed plant of most importance in Africa is the genus striga. Members of this genus are obligate annual hemiparasittes; they are chlorophyllous, but require a host to complete their life cycle. The striga flowers are pink, red, white or yellow. There is a considerable variation in flower color. The plant is characterized by herbaceous habit, small seeds and parasitism. The seeds of $S$. hermonthica are extremely small, about $0.2 \mathrm{X}$ $0.3 \mathrm{~mm}$, weighing about $0.7 \mu \mathrm{g}$. The number of seeds per capsule ranges from $700-1800$ depending on the species. The seeds can remain viable in the field for as long as 14-20 years. The minimal length of the life cycle of the parasite, from germination to seed production comprises an average of 4 months (Babiker, 2007). Since Striga is a parasitic weed the seedlings cannot sustain themselves on their own resources for particular long after germination. Therefore, they need to find a host root shortly after germination and the germination needs to be perfectly timed with the presence of a host root.

Striga has been given the common name of "witchweed" because it attaches itself to the roots of the host plant thus depriving it (the host) of water and nutrients. Striga, is a parasitic weed belonging to the Orobanchaceae (formerly: Scrophulariaceae) family (Matusova et al., 2005). S. hermonthica is common throughout northern tropical Africa and extends from Ethiopia and Sudan to West Africa. S. asiatica has a wider distribution and is found throughout semi-arid areas of tropical and subtropical Africa, Asia and Australia (Gethi and Smith, 2004). Nigeria, Sudan, Ethiopia, Mali and Burkina Faso are heavily affected counties in Africa (AATF, 2011). The host range is almost wide and besides the cultivated cereals, it attacks many of the wild grasses. The traditional crops in the African savanna attacked by the parasite are sorghum (Sorghum bicolor L., maize (Zea mays L.), pearl millet (Pennisetum glaucum L.), and sugarcane (Saccharum officinarum L.) and rice (Oriza sativa L.) (Babiker, 2007). 
Table 2. Degree of Striga infestation on crops in SSA

\begin{tabular}{llllllll}
\hline \multirow{2}{*}{ Striga species } & \multicolumn{7}{c}{ Crops } \\
\cline { 2 - 8 } S. hermonthica & $\mathrm{Xxx}$ & $\mathrm{Xxx}$ & $\mathrm{Xx}$ & $\mathrm{Xx}$ & $\mathrm{Xxx}$ & Cowpea & Sugarcane \\
\hline S. angustifolia & - & $\mathrm{Xx}$ & - & - & - & - & $\mathrm{Xx}$ \\
S. asiatica & $\mathrm{Xxx}$ & $\mathrm{Xxx}$ & $\mathrm{Xx}$ & $\mathrm{Xx}$ & $\mathrm{Xx}$ & - & $\mathrm{Xx}$ \\
S. forbesii & $\mathrm{X}$ & $\mathrm{X}$ & $\mathrm{X}$ & - & - & - & $\mathrm{X}$ \\
S. aspera & $\mathrm{Xx}$ & $\mathrm{X}$ & $\mathrm{Xx}$ & - & $\mathrm{X}$ & - & $\mathrm{X}$ \\
S. gesnerioides & - & - & - & - & - & $\mathrm{X}$ & $\mathrm{X}$ \\
S. latericea & - & - & - & - & - & - & $\mathrm{X}$ \\
S. pubiflora & - & - & - & - & - & - & $\mathrm{X}$ \\
\hline
\end{tabular}

xxx-Serious infection, $\mathrm{xx}$-Moderate infection, $\mathrm{x}$-Less infection, --No infection

Source: Parker and Riches, 1993

The Striga species are among the most specialized of all root-parasitic plant parasites (Parker and Riches, 1993). In Ethiopia, it is widely found in the lowland areas where sorghum is the dominant crop (Figure 1). Based on its infestation level sorghum yield loss due to Striga damage varies from place to place. On average sorghum yield losses of $65 \%$ were estimated in moderate to heavy infestations (Tesso et al., 2007).

Figure 1. Historically known areas with heavy Striga infestation in Ethiopia

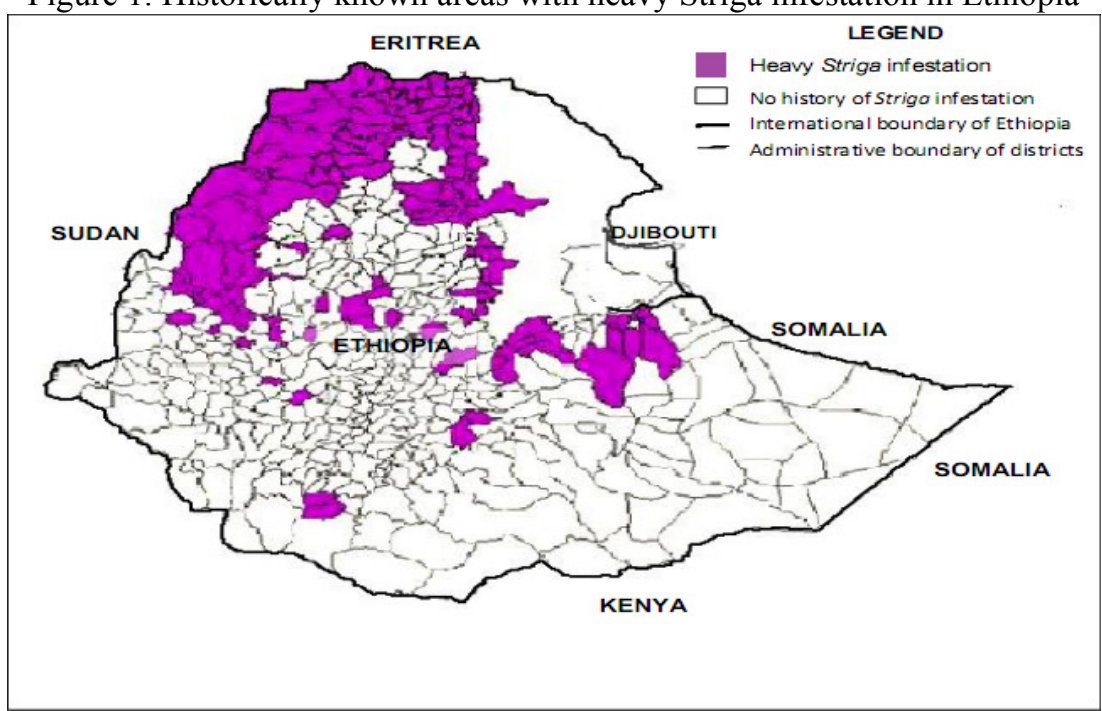

Source: Tesso et al., 2007

\section{Effect and Loss due to Striga}

Striga damage is caused by parasitism, reduction in photosynthesis and increased partitioning of photosynthates to the roots of host plants. It attaches itself to the host plant roots and in doing so, it weakens the crop plant by robbing carbon assimilates, water, nutrients and amino acids from its host (Pageau et al., 2003).

Yield losses caused by Striga are often significant and infestation by Striga usually results in substantial yield reduction often surpassing $65 \%$ in heavily infested fields. As indicated by Haussmann et al. (2000) grain yield losses of up to $100 \%$ are possible on susceptible sorghum cultivars under high Striga infestation levels. Ejeta et al. (2002) indicated that in countries such as Ethiopia and Sudan, losses of $65-100 \%$ are common in heavily infested fields but total loss can occur when Striga attack is compounded by drought. In some areas, the attack is so severe that farmers cannot grow sorghum anymore; they have either abandoned their land or switched to other less important crops (Fasil and Parker, 1994).

\section{Effects of Striga infestation on sorghum height, Leaf numbers and Sorghum dry matter}

Plant height of uninfected sorghum was significantly different from that of infected plants. Effect of Striga infestation on Sorghum height reported by Samia et al., 2014 at 8 weeks after sowing infection of sorghum variety 1 , variety 3 and variety 5 by Striga at the highest level $(4 \mathrm{mg})$ resulted in 51, 62 and $35 \%$, lower plant height than uninfected plants, respectively. However at 10 week after sowing results displayed that uninfested sorghum variety 3 sustained the highest plant $(80 \mathrm{~cm})$. Striga inoculation at 2 and $4 \mathrm{mg}$ reduced Sorghum variety 
3 height by 59 and $67 \%$, respectively as compared to uninfested control. In sorghum variety 1 Striga reduced sorghum height by 71 and $74 \%$, respectively. Therefore, research reported by Samia et al., 2014 indicated that Striga, irrespective of the levels used, reduced sorghum growth significantly, in comparison to the respective Striga free control.

Samia et al., 2014 research result displayed no significant difference in leaf number in each sorghum cultivars treated with each of the two Striga levels, irrespective. This result indicated that generally, Striga infestation had no significant effect on sorghum leaf numbers.

Total dry matter accumulation was most affected by striga infestation. Reduction in total dry matter weight under infestation was more pronounced in cultivars variety 6 and variety 5 . However, sorghum variety 5 had the lowest total dry matter, irrespective to Striga level. Cultivar variety 3 also showed no decrease in biomass or plant height on infection, but relatively high Striga emergence (Samia et al., 2014). The aboveground shoot weight and plant height of resistance varieties to the parasite were least affected by striga infestation (Bayu et al., 2001). Generally, these varieties would be interest if good yield potential were associated with their low susceptibility to striga attack.

\section{Breeding for Durable Resistance to Striga in Sorghum}

If sources of resistance have been identified, they can be incorporated for agronomic performance. Alternatively, the resistance gene in these sources can be incorporated for agronomic performance. Alternatively, the resistance genes in these sources can be obtained by pyramiding resistance genes. Crop genotypes that possess multiple genes for Striga resistance, based on distinct mechanisms, are likely to have genetic resistance that is durable across several environmental conditions as well as across ecological variants of the parasite. It has also been emphasized that breeding programs should target sources of resistance at different areas and understand the nature of resistance required (Koyama, 2000). Suggested breeding methods include: early generation selection for individual resistance mechanisms; use of recurrent selection procedures to develop breeding populations with multiple sources of resistance; lines with different resistance mechanisms are combined to form hybrids or synthetics, to increase durability of resistance and the use of marker-assisted selection techniques for the development of broad-based, quantitative resistance to witch weeds under field conditions (Haussman et al., 2000b).

\section{Breeding for Improved Integrated Striga Control Soil fertility}

Striga is more favor in less fertile soil, a system that would improve soil fertility to increase yield as well as reduce Striga infestation (Vogt et al., 1991). Severity of infestation of Striga is reported to correlate negatively with soil fertility. Nitrogen proved to be an essential element for reducing Striga infestation and mitigation of its adverse effects on crops. The suppressive effects of Nitrogen on Striga infestation were attributed to delayed germination; reduced radical elongation, reduced stimulants production and reduction of seeds response to the stimulants (Hassan et al., 2009). Good soil management practices involving the use of crop residues and organic manure have been effective control measure against Striga (Vogt et al., 1991). Result reported by Zerihun, 2016 indicated that interaction effect of nitrogen rates by variety on number of S. hermonthica at 10 and 12 weeks after planting was number of striga in variety Gubiye, Hormat and Teshale decreases respectively when the nitrogen rates increases. This result concluded that Striga infestation decreased with increasing nitrogen rates. In addition, resistances variety hosting number of striga more decreases than other varieties when nitrogen rate increases.

Striga infestation decreased with increasing organic matter of the soil and that organic matter content seemed to be the most important factor which preserved the soil fertility. Since soil microbial biomass flourishes better in a medium rich in organic matter, organic or inorganic soil amendments may increase soil suppressiveness to Striga spp. and also improve soil conditions to increase yield of subsequent cereals (Berhane, 2016).

\section{Inter cropping}

Intercropping sorghum with legumes consistently provides significant seasonal control of Striga and enhanced grain yields. The overall effect however showed that intercropping sorghum with soybean and groundnut led to a reduction in Striga number at simultaneous intercropping rather than relay cropping. Intercropping with these legumes therefore showed some promise as a suitable component of an integrated Striga management approach for the small holder farmers, but this would need to be combined with other cultural methods such as hand weeding of emerged Striga to avoid replenishment of Striga seed bank in the soil (Fitsum et al., 2016). Some studies indicate that intercropping with cowpeas between the rows of maize significantly reduced Striga numbers when compared to within the maize rows (Odhiambo and Ransom, 1993). Moreover, finger millet intercropped with green leaf desmodium reduced Striga hermonthica counts in the intercrops than in the monocrops (Midega 
et al., 2010). According to (Fasil et al., 2005) also reported related findings on sorghum cowpea intercropping where Striga emergence was lower under intercrops than sole crops. Generally, various studies have shown that intercropping cereals, mainly with legumes such as cowpea, peanut and green gram can reduce the number of Striga plants (Carsky et al., 2000). Potentially they might be acting as traps crops and interfere with Striga germination and development (Parker and Riches, 1993).

\section{Host plant resistance}

Striga resistance is the ability of the host root to stimulate Striga germination but at the same time prevent attachment of the seedlings to its roots or to kill the seedlings when attached. The use of resistant crop cultivars is the most economically feasible and environmentally friendly means of Striga control. In East Africa, the most promising new approach to Striga control is the use of resistant cultivars for instance sorghum. Striga resistant cultivars have been bred in a number of crops. However, cultivars with immunity to Striga have not been found in all host crops. The host/parasite relationship is governed by a series of steps involving stimulation of germination, haustorium initiation, penetration of the host root, connection to the host xylem and concurrent growth (Butler, 1993).

Result reported by Gobena et al., 2017 sorghum seedlings with high Striga germination stimulant activity (A) will germinate conditioned S. asiatica seeds cocultured in agar, a centimeter or more from its root as the germination stimulant, 5-deoxystrigol, diffuses through the medium. Low-stimulant sorghum that exudes orobanchol instead of 5-deoxystrigol will not cause S. asiatica seeds to germinate in the agar gel assay, even very near its roots (B). (Scale bars, $1 \mathrm{~mm}$.) The photograph (C) shows an LGS1 WT high-stimulant sorghum (left) growing next to a line (right) carrying the lgs $1-1$ allele in a field infested with S. hermonthica (purple flowers) in Ethiopia.

\section{Integrated Striga management}

No single management option has been found effective across locations and time. An integrated Striga management approach, currently, offers the best possibility for reducing impact at the farm level. (Evans et al., 2011) reported suitable management Striga control strategies aimed at improving and filling in the gaps of the available mechanisms which have not been widely adopted by farmers. Priority should be geared towards understanding the parasite and the farmers farming systems so that any mechanism developed will be able to fit into the farmers' requirements. In addition breeding of cultivars that are resistant to Striga will be cost-effective to control the parasite as cultivation of resistant varieties does not require costly inputs from farmers. If at all resistant genes can be identified, they can be transferred to other cereals such as maize, millet and sorghum by marker-assisted selection.

A similar study by (Temam, 2006) pointed out that species of Striga were controlled by using the resistant variety, fertilizer and tied ridges on farms of eastern Ethiopia which had long been abandoned due to Striga infestation. Species of Striga were controlled by using the resistant variety, fertilizer and tied ridges on farms; whereas, the local cultivar had severe infestations. The Striga-infested local varieties died, failed to produce a head or had very small heads. Striga count against treatment and yield against treatment were significant at $p \leq$ 0.01. Striga count against location and yield against location were not significant (Temam, 2006).

\section{Field screening}

Conventional plant breeding for Striga resistance has traditionally involved field evaluation of germplasm under artificial or natural infestation. The agar-gel assay is an excellent tool to screen host genotypes in the laboratory for low production of the striga seed germination stimulant. Field screening for striga resistance is hampered by high microvariability in African soils, heterogeneity of natural infestations, and concomitant large environmental effects on striga emergence (Haussmann et al., 2000). The efficiency of striga resistance breeding in sorghum could be further increased by combining laboratory assays with the field evaluation, and by the development of marker-assisted selection techniques. For effective striga control, resistant cultivars must be integrated with other control methods such as crop rotation (Haussmanna et al., 2000).

\section{Breeding Strategies}

Both interspecific variability among Striga species and intraspecific variation for aggressiveness must be taken into account when breeding for striga resistance (Ramaiah, 1987; Ejeta et al., 1992). In order to obtain stable, polygenic resistance, breeding materials should be evaluated at various locations with different striga populations or host-specific races (Ramaiah, 1987). In doing so, quarantine regulations must be strictly respected, and striga species or strains should not be introduced into regions where they do not already occur. If seed shortage imposes a constraint on progeny evaluation, a reduction in plot size should be preferred over reduction of the number of test locations, since there is always the danger of losing data from one location due to "nonstriga years" or other obstacles. To avoid seed shortage and therefore a trade-off between replications and sites, 
breeders could use inbred generations as test entries (Kling et al., 2000).

The fact that the low stimulant gene(s) were reported to be recessive renders the back-cross program more complicated and time-consuming. With its high heritability and the possibility to screen large numbers of entries, the in vitro germination distance fulfills two major prerequisites for an indirect selection trait. Coefficients of correlation between germination distance and striga resistance under field conditions are generally positive but vary among genetic materials and test locations (Vasudeva Rao, 1985; Omanya et al., 2000). In trials involving a recombinant inbred population derived from the cross of line IS 9830 (low stimulant) with line E 36-1 (high stimulant), coefficients of correlation between germination distance in the agar-gel assay and striga emergence in the field ranged between 0 and 0.32 (significant at P.0.01) in Kenya, and between 0.29 and 0.64 (both significant at P.0.01) in Mali (Omanya et al., 2000).

\section{CONCLUSION}

Some sorghum genotypes support significantly fewer Striga plants and give higher grain yield than others. Some other genotypes show smaller yield reductions than others under the same level of infestation. Some are highly susceptible and would not give yield at all. The presence of this wide range of variability in Striga resistance and tolerance traits among sorghum genotypes suggests an opportunity to develop high yielding and resistant/tolerant genotypes through hybridization.

Developing Striga resistant genotypes is the most promising, practical, and cost effective approach to reduce effects of Striga. Also, resistance cultivars is a major component of integrated control packages. Therefore, future research efforts should be directed towards understanding host resistance mechanisms, improvement of field screening and infestation techniques, and development of stable high yielding Striga resistant varieties that are acceptable to farmers.

The screening strategy could be to use laboratory assays for individual resistance mechanisms as an initial screening of a larger number of breeding materials, followed by the more resource-demanding field screening. Networking and exchange of useful materials are also important steps towards more efficient breeding programs for resistance to striga in sorghum.

Numerous sorghum cultivars or breeding lines have been reported as resistant to striga. However, Sorghum breeding program finding would not only show how striga reduced the performance and yield of the different sorghum varieties but, also assist farmers in choosing the best variety of sorghum to cultivate under striga infestation.

\section{REFERENCES}

AATF (African Agricultural Technology Foundation), 2011. Feasibility Study on Striga Control in Sorghum. African Agricultural Technology Foundation, Nairobi. ISBN 9966-775-12-9.

Ast,A.Van, 2006. The influence of time and severity of striga infection on the sorghum bicolor-striga hermonthica association. PHD thesis, Wageningen University, Wageningen, The Netherlands, with Summaries in English, French and Dutch, pp 154.

Babiker AGT, 2007. Striga: The Spreading Scourge in Africa. Regul.Pl. Grow. and Devel, 42: 74-87.

Bayu W., Binor S. and Admassu L., 2001. Tolerance of sorghum landraces and varieties to striga( striga hermonthica) infestation in Ethiopia. Acta Agronomic Hungarica, 49:343-349.

Berhane Sibhatu, 2016. Review on Striga Weed Management. Int. J. Life. Sci. Scienti. Res., VOL 2:110-120.

Beyene Amelework, Hussien Shimelis, Pangirayi Tongoona, Mark Laing and Fentahun Mengistu, 2016. Genetic diversity of lowland sorghum landraces assessed by morphological and microsatellite markers. AJCS 10(3):291-298.

Butler LG, 1993. Chemical Communication between the Parasitic Weed Striga and its host crop, a new dimension in allelo-chemistry, In: Ml Dakshini and FA Einhelling (eds). Allelopathy: Organisms, Processes, and Application. ACS Symposium Series 582, American Chemical Society. Washington DC., USA.

Carsky RJ, Berner DK, Oyewole BD, Dashiell K and Schulz S, 2000. Reduction of Striga hermonthica parasitism on maize using soybean rotation. International Journal of Pest Management, 46:115-120.

Dahlberg J, Berenji J, Sikora V and Latkovic D, 2011. Assessing sorghum [Sorghum bicolor (L) Moench] germplasm for new traits: food, fuels \& unique uses. Advance Access publication Maydica 56-1750.

Ejeta, G., Butler, L.G., Babiker, A.G., 1992. New approaches to the control of Striga. Striga Research at Purdue University, Research Bulletin RB-991. Agricultural Experiment Station, Purdue University.

Ejeta, G., Babiker, A.G.T. and Butler, L. 2002. New approaches to the control of Striga, a training workshop on Striga resistance. Melkassa, May 14-17,(2002). Nazareth, Ethiopia.

Ejeta G., 2005, Integrating biotechnology, breeding and agronomy in the control of the parasitic weed Striga spp. in sorghum. Pp 239-251.

Evans A. Atera, Kazuyuki Itoh and John C. Onyango, 2011. Evaluation of ecologies and severity of Striga weed on rice in sub-Saharan Africa. Agriculture And Biology Journal Of North America 2:752-760. 
Fasil R, and Parker C, 1994. Distribution and importance of Striga and related parasitic weeds in Ethiopia. In: Lagoke et al. (eds) Proceedings of the 2nd general workshop of the Pan African Striga control, Nairobi, Kenya, pp. 157-163.

Fasil R, Verkleij JAC, and Ernst WHO, 2005. Intercropping for the Improvement of Sorghum Yield, Soil Fertility and Striga Control in the Subsistence Agriculture Region of Tigray (Northern Ethiopia).Journal of Agronomy and Crop Science, 191:10-19.

Fitsum Merkeb, Zewdineh Melkei, Tesfa Bogale, Abuhay Takele, 2016. Influence of intercropping sorghum with legumes to control striga (Striga hermonthica) in Pawe, North Western Ethiopia. World Scientific News 53(3):204-215.

Gethi JG and Smith ME, 2004. Genetic responses of single crosses of maize to Striga hermonthica (Del.) Benth and Striga asiatica (L.) Kuntze. Crop Sci, 44: 2068- 2077.

Gobena, Shimels, Rich, Ruyter-Spira, Bouwmeester, Kanugantia, Mengiste, and Ejeta, 2017. Mutation in sorghum LOW GERMINATION STIMULANT1 alters strigolactones and causes Striga resistance. vol. 114:4471-4476.

Hassan, M.M., Abdelgain, M.E. and Babiker, A.G.T., 2009. Potential of Bacterial Strains and Nitrogen in Reduction of Striga Hermonthica (Del.) Benth. Infesting Sorghum,America- Eurasian Journal of Sustainable Agriculture, 3(1): 1-9.

Haussmann, B.I.G., Hess, D.E. Weiz, H.G. and Geiger, H.H. 2000. Improved methodologies for Breeding, Striga resistant sorghums.

Haussmann, B.I.G., Hess, D.E., Reddy, B.V.S., Mukuru, S.Z., Kayentao, M., Welz, H.G., Geiger, H.H., 2000b. Diallel studies on striga resistance in sorghum. In: Haussmann, B.I.G., Koyama, M.L., Grivet, L.,

Hayelom Berhe Teka, 2014. Advance research on Striga control: A review. African Journal of Plant Science Vol. 8, pp. 492-506.

Kling, J., Fajemisin, J.M., Badu-Apraku, B., Diallo, A., Menkir, A., Melake-Berhan, A., 2000. Striga resistance breeding in maize.

Koyama, M.L., 2000. Genetic variability of Striga hermonthica and effect of resistant sorghum cultivars on population dynamics.

Matusova R, Rani K, Verstappen FWA, Franssen MCR, Beale MH and Bouwmeester HJ, 2005. The strigolactone germination stimulants of the plant- parasitic Striga and Orobanche spp. are derived from the carotenoid pathway. Plant Physiology, 139: 920- 934.

Mekonen Sime, 2007. Assessment of Factors Influencing Adoption of Integrarted Striga Management Technologies of Sorghum in Habro and Fedis Woredas. Oromia Region. Haramey University. pp 1-6.

Mesfin Abate, 2016 Assessment of Striga infestation and Evaluation of sorghum landraces for Resistance/Tolerance to [Striga hermonthica (Del.) Benth] in North-Western Ethiopia.

Midega CAO, Khan ZR, Amudavi DM, Pittchar J and Pickett JA, 2010. Integrated management of Striga hermonthicaand cereal stem borers in finger millet [Eleusinecoracana (L.) Gaertn.] through intercropping with Desmodiumintortum. International Journal of Pest Management, 56:145-151.

Ministry of Agriculture and Rural Development, 2009. Crop Variety Register issue no. 12. Addis Ababa, Ethiopia.

Monica A. Menz, Robert R. Klein, Natalie C. Unruh, William L. Rooney, Patricia E. Klein and John E. Mullet, 2004. Genetic Diversity of Public Inbreds of Sorghum Determined by Mapped AFLP and SSR Markers. Published in Crop Science. 44:1236-1244.

Mutengwa, C. S., Tongoona, P. B. and Sithole-Niang, I., 2005. Genetic studies and a search for molecular markers that are linked to Striga asiatica resistance in sorghum. African Journal of Biotechnology, 4:1355136

Obilana, A.T., and Ramaiah, K.V. 1992. Striga (witchweeds) in sorghum and millet: knowledge and future research needs. Pages 187-201 in Sorghum and millets diseases: a second world review, (de Milliano, W.A.J., Frederiksen, R.A., and Bengston, G.D., eds). Patancheru, A.P. 502 324, India: International Crops Research Institute for the Semi-Arid Tropics. (CP 741).

Odhiambo GD, and Ransom JK, 1993. Effect of dicamba on the control of Striga hermonthica in maize in western Kenya. African Crop Science Journal, 1:105-110.

Omanya, G.O., Haussmann, B.I.G., Hess, D.E., Reddy, B.V.S., Mukuru, S.Z., Welz, H.G., Geiger, H.H., 2000. Evaluation oflaboratory, pot, and field measures of striga resistance in sorghum.

Pageau, K., Simier, P. Le Bizec, B. Robins R. J. and Fer, A. 2003. Characterization of nitrogen relationships between Sorghum bicolor and the root-hemiparasitic angiosperm Striga hermonthica (Del.) Benth.

Parker C and Riches CR, 1993. Parasitic Weeds of the World: Biology and Control. Wallingford CAB International.

Ramaiah, K.V., 1987. Breeding cereal grains for resistance to witchweed. In: Musselman, L.J. (Ed.), Parasitic Weeds in Agriculture, Vol. I 
Rich, P.J., Grenier, C., and Ejeta, G. 2004. Striga resistance in the wild relatives of sorghum.

Samia O., Mohammed. M., Migdam E. and Abdel El Gabar E., 2014. Screening Sorghum for Resistance To Striga Hermonthica (Del.) Benth. Nova Journal of Medical and Biological Sciences Vol 2(4):1-7.

Tadesse T, Tesso T, and Ejeta G., 2008. Combining ability of introduced sorghum parental lines for major Morpho-agronomic traits. Journal of SAT Agricultural Research 6.

Temam T., 2006. Distribution of two Striga species and their relative impact on local and resistant sorghum cultivars in East Ethiopia. Wiley Inter Science, Trop. Sci,46(3), 147-150.

Tesso, T., Zenbaba, G., Aberra, D., and Ejeta, G. 2007. An integrated Striga management option offers effective control of Striga in Ethiopia. p.199-212. In: Ejeta, G. and Gressel, J. (eds). Integrating New Technologies for Striga Control: Towards Ending the Witch-hunt. World Scientific Publishing Co., Singapore.

Vasudeva Rao, M.J., 1985. Techniques for screening sorghums for resistance to Striga. ICRISAT Information Bulletin No. 20.

Vogt W, Saurborn J and Honisch M, 1991. Strigahermonthica, distribution and infestation in Ghana and Togo on grain crops. In: Ransom JK, Musselman LJ, Worsham AD and Parker C (Eds.), Proceedings of the Fifth International Symposium on Parasitic Weeds. CIMMYT, Nairobi, Kenya. pp. 272-277.

Zerihun Sarmiso, 2016. Effect of Nitrogen Fertilizer on Striga Infestation, Yield and Yield Related Traits in Sorghum [(Sorghum Bicolor (L.)Moench] Varieties at Kile, Eastern Ethiopia. Journal of Biology, Agriculture and Healthcare Vol.6. 